\title{
Linear Peptide Analogues from Jatropha's Orbitides Promote Migration of Human Neonatal Foreskin Fibroblasts in vitro and Collagen Deposition
}

\author{
Suelem D. Ramalho, ${ }^{\circledR a}$ Meri Emili F. Pinto, ${ }^{\circledR a}$ Renata K. Andricopulo, ${ }^{b}$ \\ Paulo R. S. Sanches, ${ }^{a}$ Edilberto R. Silveira, ${ }^{\circledR c}{ }^{c}$ Eduardo M. Cilli, ${ }^{a}$ \\ Adriano D. Andricopulo ${ }^{b}$ and Vanderlan S. Bolzani ${ }^{\oplus *, a}$ \\ anstituto de Química, Universidade Estadual Paulista (Unesp), 14800-060 Araraquara-SP, Brazil \\ ${ }^{b}$ Instituto de Física de São Carlos (IFSC), Universidade de São Paulo (USP), \\ 13566-590 São Carlos-SP, Brazil \\ ${ }^{c}$ Departamento de Fisiologia e Farmacologia, Universidade Federal do Ceará (UFC), \\ 60430-270 Fortaleza-CE, Brazil
}

\begin{abstract}
Orbitides are a class of small naturally occurring cyclic peptides with structural and functional diversities. Their chemical properties make this class feasible to be obtained by solid phase peptide synthesis (SPPS). Therefore, this synthetic accessibility enables useful application and facilitates the identification of analogues, bioactivity studies, and thus, enables them to be applied to obtain peptide libraries. The aim of this work was to investigate the effects of orbitides and their linear synthetic analogues on the migration of neonatal human foreskin fibroblasts. The screening of linear peptide analogues, originally designed from natural orbitides isolated from Jatropha species, demonstrated that some molecules (linear pohlianin B and linear ribifolin) have the potential to induce fibroblast migration and collagen deposition and may thus contribute to accelerating the processes of wound healing and tissue repair. These results also demonstrate the significance of using peptides as an important tool for the discovery of simple and novel drug scaffolds.
\end{abstract}

Keywords: Jatropha, orbitides, linear analogues, fibroblast migration

\section{Introduction}

Peptides play an important role in many cellular processes in living organisms, including plants. They represent a group of natural products with great functional diversity and have a range of therapeutically relevant bioactivities, being useful in many applications such as cosmetics, agriculture and drug design. ${ }^{1}$ According to the number of amino acids, the type of cyclization and disulfide bonding, naturally cyclic peptides from plants can be classified as orbitides, trypsin inhibitors and cyclotides. Orbitides are plant-derived cyclic peptides with low molecular weight that have a ribosomally synthesized sequence of 5 to 12 amino acids, a lack of disulfide bonds and head-tail cyclization as a post-translational modification. They have been documented in families including Annonaceae, Euphorbiaceae, Lamiaceae, Linaceae, Phytolaccaceae, Rutaceae, Schizandraceae and Verbenaceae. ${ }^{2-5}$

*e-mail: bolzaniv@iq.unesp.br
In recent decades, the Jatropha genus (Euphorbiaceae family) has emerged as a rich source of bioactive orbitides. ${ }^{5,6}$ Plants from this genus are endemic in the Brazilian semi-arid region (Caatinga biome) ${ }^{7}$ and represent a popularly known source of toxins and medicines. Furthermore, the pharmacological activities of orbitides have been described as antimicrobial, cytotoxic, antimalarial, immunomodulators and inhibitors of aspartyl proteases. ${ }^{2,8,9}$ The relationship of the activities of these peptides with their compositions, amino acid sequences, spatial arrangements, charges and cyclization should be taken into consideration. Highlighting the importance of structural diversity, solid phase peptide synthesis (SPPS) is a convenient and useful approach to obtain peptide analogues; this method allows molecules with chemo-diversity to be obtained in appropriate amounts, thus helping to drive their applications as drug scaffolds. ${ }^{10,11} \mathrm{In}$ plants, they are usually produced in minimal yield.

Recently, interest regarding peptides and proteins for drug design has strongly increased based on their 
existing applications. ${ }^{12,13}$ Through 2017, over 60 peptide drugs have been approved in the United States, Europe and Japan; over 150 are in active clinical development, and an additional 260 have been tested in human clinical trials. These molecules are usually derived from natural sources (native), through synthetic modifications of native compounds (analogue), or through recombinant expression (heterologous). ${ }^{12}$ The majority present sizes ranging from 8 to 10 amino acids, and they have been investigated as a treatment of a wide range of diseases, thus comprising a large field within the pharmaceutical industry. ${ }^{13}$

Defective healing of chronic wounds is a serious clinical problem that has been investigated, and the migration of fibroblasts is described as one of the most important processes involved in wound healing and tissue repair. ${ }^{14}$ Fibroblasts are mesenchymal cells representing the primary source of extracellular matrix and collagen, which are the principal active cells of connective tissues. ${ }^{15,16}$ In response to injury, fibroblasts in the vicinity of the wound begin to proliferate and migrate into the wound at an early stage. There are additional compounds and cell types that are involved in this event, such as growth factors, cytokines, and immune and endothelial cells. ${ }^{17,18}$ Studies have also described that alterations in cell migration might be associated with diabetes and cutaneous injury since deficient wound healing is very frequent in these types of conditions. ${ }^{14,16}$ Therefore, cell migration may represent a target for therapeutic intervention once novel strategies are developed.

Recognizing the potential of peptides as novel therapeutics, we synthesized a series of linear peptide analogues (1a-4a) based on natural orbitides (1-4) isolated from two Jatropha species, i.e., Jatropha mollissima (Pohl) Baill. (syn. J. pohliana ssp. mollissima) and Jatropha ribifolia (Pohl) Baill. All compounds were evaluated with respect to HFF-1 (neonatal human foreskin fibroblast) migration and collagen deposition.

\section{Results and Discussion}

\section{Jatropha's orbitides and synthetic analogues}

The latex from the Jatropha plant species is usually characterized as the main source of orbitides, which also are accumulated in other parts of the plant such as the leaves, roots and stem bark. Chemical studies on Jatropha Brazilian species led to the isolation of some natural orbitides already described in the literature. Thus, from the latex of Jatropha mollissima (Pohl) Baill. (syn. J. pohliana ssp. mollissima), pohlianin $\mathrm{A}(\mathbf{1}),{ }^{19} \mathrm{~B}(\mathbf{2})^{19}$ and $\mathrm{C}(\mathbf{3})$ were isolated, ${ }^{19}$ and from the aerial parts of
Jatropha ribifolia (Pohl) Baill., ribifolin (4) was obtained. ${ }^{8}$ All mentioned orbitides from the Jatropha genus consist of L-amino acids and are characterized by the preponderance of hydrophobic amino acids. Figure 1 presents the chemical structures of the naturally occurring orbitides. They were numbered according to the Cahn-Ingold-Prelog (CIP) rules, which prioritize the amino acid residues based on their atomic compositions. In order to facilitate comparison, a standard orbitides nomenclature was established according to the literature..$^{20}$ For confirming the orbitides structures, mass spectrometry and tandem mass spectrometry (MS/MS) analyses were recorded and matched with the previous data for the plant-derived cyclic peptides (1-4) ${ }^{8}{ }^{819}$ These methods also confirmed the molecular formula and subsequent losses of amino acid residues (see Figure S1 in the Supplementary Information (SI) section). Table 1 shows the peptide sequences and the observed molecular masses.

Peptides can be obtained either from natural plant material or by chemical synthesis. A known fact is that some structural features might interfere with their biopharmaceutical properties. ${ }^{13}$ In order to investigate whether the modifications including cyclization, charges and spatial arrangement contribute to fibroblast migration and collagen deposition, we synthesized the corresponding linear analogues of the mentioned natural orbitides (1-4). Furthermore, the isolation of all linear analogues (1a-4a) was accomplished using SPPS method based on the Fmoc (9-fluorenylmethoxycarbonyl) strategy. After complete chain assembly, the amino terminal region was deprotected and the linear peptides were cleaved from the solid support by using TFA (trifluoroacetic acid) and precipitated with diethyl ether. In a general way, the acyclic molecules can be obtained in different forms because the SPPS Fmoc can start at any amino acid residue. Based on this statement, we started the synthesis with the Fmoc-L-Gly Wang resin, which was chosen based on the availability of this resin in our laboratory. Thus, glycine (Gly) was the first amino acid in the linear sequence of the synthetic peptide analogues (Table 2). Following this approach, the amino acid sequences of linear pohlianin A (1a), B (2a) and C (3a) were described as Val-Leu-Leu-Tyr-Pro-Leu-Gly, Leu-Leu-Leu-Tyr-Pro-Leu-Gly and Gly-Thr-Ile-Ile-PheGly-Phe-Gly, respectively. For linear ribifolin (4a), the sequence was determined as Ile-Leu-Gly-Ser-Ile-Ile-LeuGly. During the biosynthesis of orbitides, and at the time of ring closure, a loss of a water molecule (dehydration reaction) occurs; although characterized by an open ring, all linear analogues present an increase of $18 \mathrm{Da}$ in the molecular weight value, which is commonly detected by mass spectrometry analysis (Figure S2 in the SI section). 


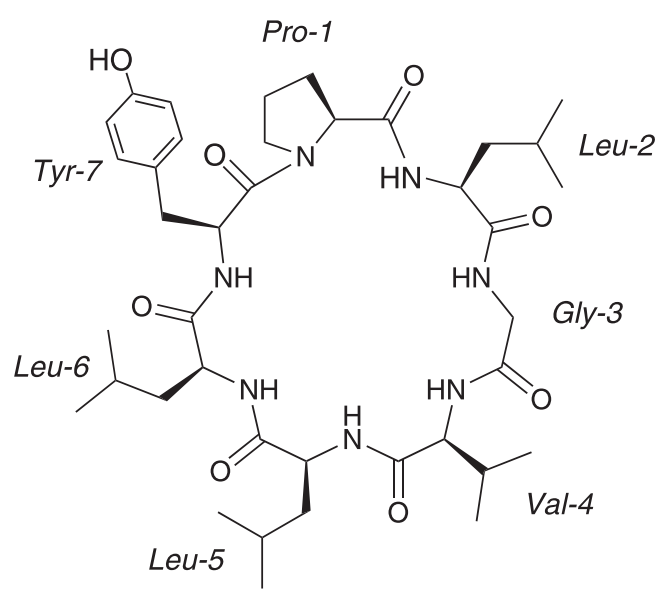

Pohlianin A (1)<smiles>CCC(C)[C@@H]1NC(=O)[C@H](Cc2ccccc2)NC(=O)[C@@H](C(C)CC)NC(=O)[C@H](C(C)C)NC(=O)CNC(=O)CNC(=O)[C@H](Cc2ccccc2)NC(=O)CNC(=O)[C@H](Cc2ccccc2)NC1=O</smiles>

Pohlianin C (3)

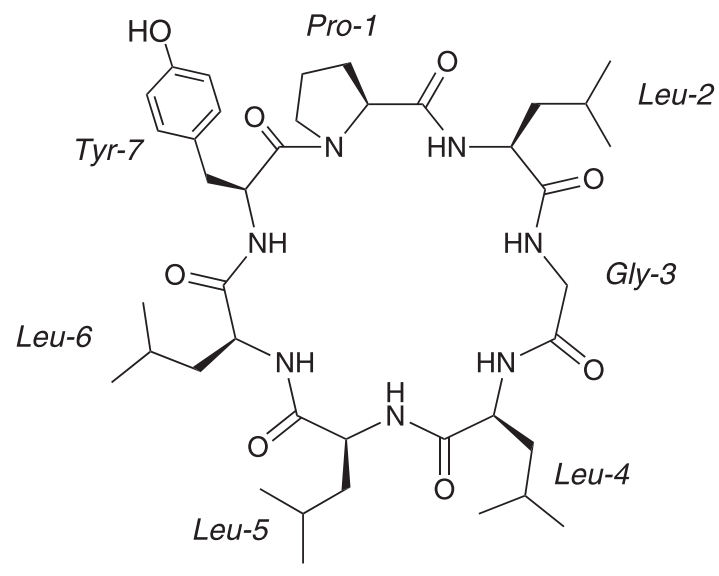

Pohlianin B (2)

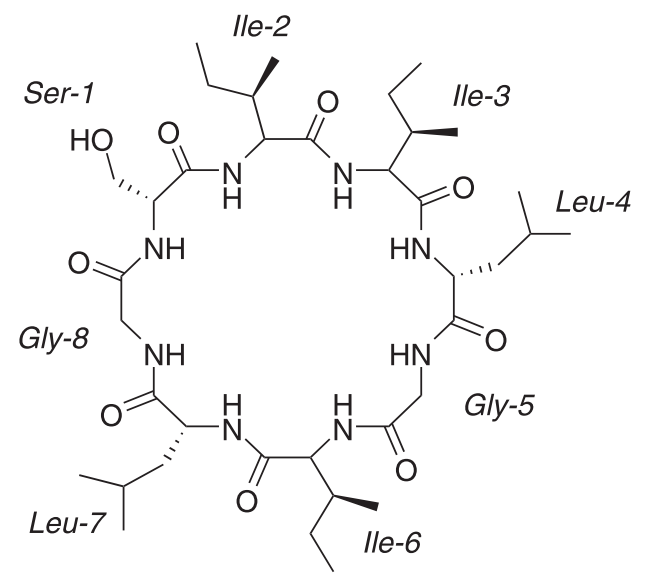

Ribifolin (4)

Figure 1. Chemical structures of orbitides from Jatropha spp.: pohlianin A (1), B (2), C (3) and ribifolin (4).

Table 1. Sequences and masses of orbitides

\begin{tabular}{lccc}
\hline Number & Name & Proposed nomenclature and sequence ${ }^{\mathrm{a}, 3}$ & Mass $^{\mathrm{b}} / \mathrm{Da}^{\mathrm{a}}$ \\
\hline $\mathbf{1}$ & pohlianin A & {$[1-7-\mathrm{N} \alpha \mathrm{C}]$-jatpoorb A, PLGVLLY } & 756.46 \\
$\mathbf{2}$ & pohlianin B & {$[1-7-\mathrm{N} \alpha \mathrm{C}]$-jatpoorb B, PLGLLLY } & 770.48 \\
$\mathbf{3}$ & pohlianin C & {$[1-8-\mathrm{N} \alpha \mathrm{C}]$-jatpoorb C, TIIFGFGG } & 793.42 \\
$\mathbf{4}$ & ribifolin & {$[1-8-\mathrm{N \alpha C}]$-jatriorb A, SIILGILG } & 767.47 \\
\hline
\end{tabular}

${ }^{a}[1-\#-\mathrm{N \alpha C}]$ indicates the linkage between amino acid 1 and amino acid \# through an $\alpha$-amino group which is a N-C cyclization; bobserved by ESI-MS, positive mode $[\mathrm{M}+\mathrm{H}]^{+}$. All peptides present purity higher than $95 \%$ confirmed by HPLC analysis.

\section{In vitro fibroblast assays}

Fibroblast migration and proliferation are essential events involved in the process of tissue repair. We carried out a quantitative characterization through concentrationresponse transwell migration assays (Boyden chamber assay). Using a bioactivity-guided fractionation, we submitted the crude extracts from Jatropha species
(CE-JM and CE-JR) to the neonatal human foreskin fibroblast (HFF-1) in vitro assays. They presented moderate activity (Figure 2 ) with concentrations of $20 \mu \mathrm{g} \mathrm{mL}^{-1}$. The extracts of CE-JM and CE-JR showed migration values of 215 and 422, respectively. In an effort to establish a relationship between the chemical structures of peptides and fibroblast migration, all naturally occurring orbitides (1-4) and their synthetic analogues (1a-4a) were evaluated 


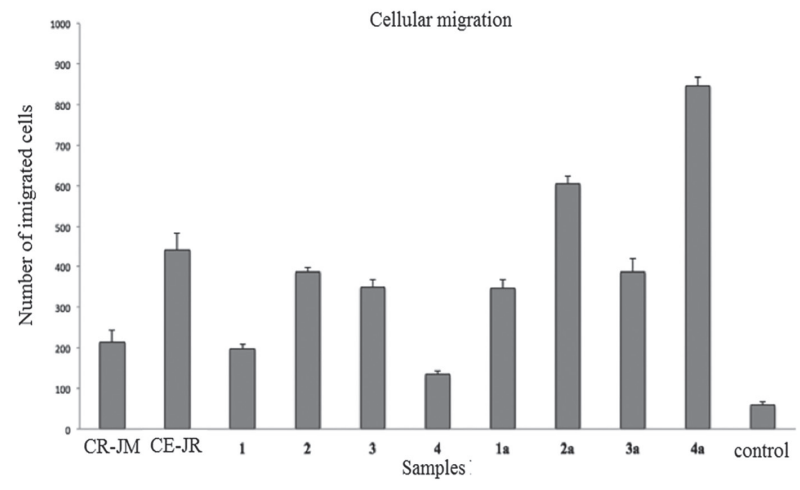

Figure 2. Boyden chamber evaluation of crude extracts and peptides. Bar graphs represent the number of migrated neonatal human foreskin fibroblasts (HFF-1). Data represent the average of triplicate determinations \pm standard deviation.

by HFF-1 in vitro assays. This test compares well to the wound healing assay. The present investigation (Figure 2) demonstrated that the linear analogues $2 \mathbf{a}$ and $4 \mathbf{a}$ were the most potent peptides, promoting high fibroblast migration at the concentration of $5 \mu \mathrm{M}$.

The obtained values for peptides $\mathbf{2 a}$ (604) and $\mathbf{4 a}$ (847) suggested that these compounds have important features that allow the migration of the HFF-1 cells. In fact, we would like to demonstrate whether the cyclic backbone and the internal hydrogen bonds were involved in the migration effect or not. The comparison of orbitide $\mathbf{4}$ and the respective linear analogue (4a) demonstrated a substantial increase with respect to HFF-1 cell migration. The same evaluation was performed for peptides $\mathbf{2}$ and 2a, obtaining similar results. Thus, data presented herein suggest that the cyclization of peptides may not contribute to the migration effect since orbitides presented only moderate activity and exhibited less potent effects. In a general way, we can assume that the presence of charges and the spatial arrangements of these linear peptides contributed to the events since linearity has been found to be a useful modification to improve fibroblast migration.

Linear peptides are characterized by C-terminal and $\mathrm{N}$-terminal charges, which somehow might be associated with fibroblast migration. Comparing the amino acid sequences of the linear peptides $\mathbf{1 a}$ and $\mathbf{2 a}$, which are known to be very similar compounds, the primary difference between them is only the substitution of a valine (Val) by a leucine (Leu) (Table 2), but they may also differ in their spatial conformations. Regarding the Boyden chamber assay, the value obtained for $2 \mathrm{a}$ (604) was approximately 1.5 times higher than that of peptide 1a (348). Thus, it can be suggested that the presence of this amino acid (Leu) may be related and somehow contributing to the fibroblast migration.

The medium was supplemented with FBS (fetal bovine serum). FBS stimulates the movement of cells and served
Table 2. Amino acid sequences and masses of linear peptides (1a-4a)

\begin{tabular}{lccc}
\hline Number & Peptide & Sequence & Mass $^{\mathrm{a}} / \mathrm{Da}$ \\
\hline 1a & linear pohlianin A & VLLYPLG & 774.47 \\
2a & linear pohlianin B & LLLYPLG & 788.49 \\
3a & linear pohlianin C & GTIIFGFG & 811.43 \\
4a & linear ribifolin & ILGSIILG & 785.47 \\
\hline
\end{tabular}

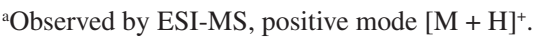

as a positive control on each plate to ensure that the cells spread on the plate possessed the ability to migrate under the culture conditions. We used media supplemented with $10 \% \mathrm{FBS}$ as a positive control and serum-free media as a true negative control (Figure 3).

Additionally, a wound healing scratch assay (qualitative analysis) was performed to determine the effect of the most potent peptides, 2a and $\mathbf{4 a}$, on HFF-1 fibroblast migration (Figure 4). At the end of the experiment (16 h), positive results were obtained and the complete closure of the gap was verified by the HFF-1 fibroblasts that migrated in the presence of $\mathbf{2 a}$ and $\mathbf{4 a}$. These findings confirm the high potential and indicate that these two linear peptides represent promising novel lead candidates in the search for tissue repair drugs.

Prior to the cell evaluation, we initially carried out a cytotoxic assay because toxicity would preclude trials for those molecules. A number of studies reported that the MTS (3-(4,5-dimethylthiazol-2-yl)5-(3-carboxymethoxy phenyl)-2-(4-sulfophenyl)$2 \mathrm{H}$-tetrazolium) in vitro cytotoxicity assay is a convenient method for assessing cell viability. The main features offered by this assay are the accuracy and rapid indication of toxicity. Both 2a and 4a peptides were evaluated for their cytotoxic effects against fibroblasts at two concentrations (1 and $20 \mu \mathrm{M}$ ) over 24 and $72 \mathrm{~h}$. The results obtained from the MTS assay demonstrated that the evaluated peptides are nontoxic to the HFF-1 cells (Table S1 in the SI section).

Furthermore, peptides $\mathbf{2 a}$ and $\mathbf{4 a}$ were selected for analysis involving capillary tubule formation and hydroxyproline content (Figures 5 and 6). The in vitro tubule assay is a model used to understand the developing vasculature since the ability of fibroblast migration might be critical to the creation of new vessels and capillaries. This assay provides evidence that cells can proliferate and originate new cells resembling endothelial cells. The stimulation of this process is an important tool as it is heavily involved in wound healing and tissue repair. ${ }^{21,22}$ Tubule development was observed over a 0-6-hour time period in Matrigel using a peptide concentration of $20 \mu \mathrm{M}$. 

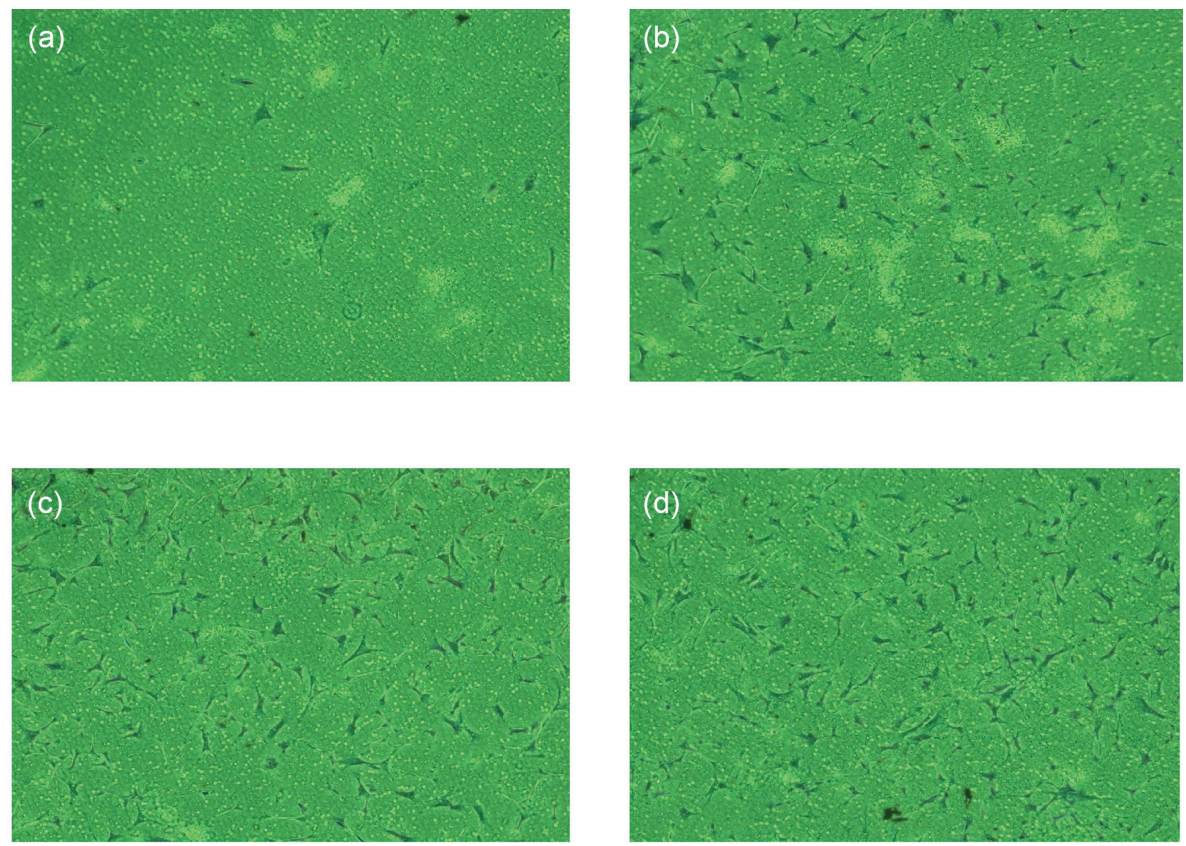

Figure 3. Representative images of the most potent peptides evaluated in the Boyden chamber assay (HFF-1 fibroblasts): (a) negative control, (b) positive control, (c) linear pohlianin B (2a) and (d) linear ribifolin (4a) at the concentration of $5 \mu \mathrm{M}$.

(a)
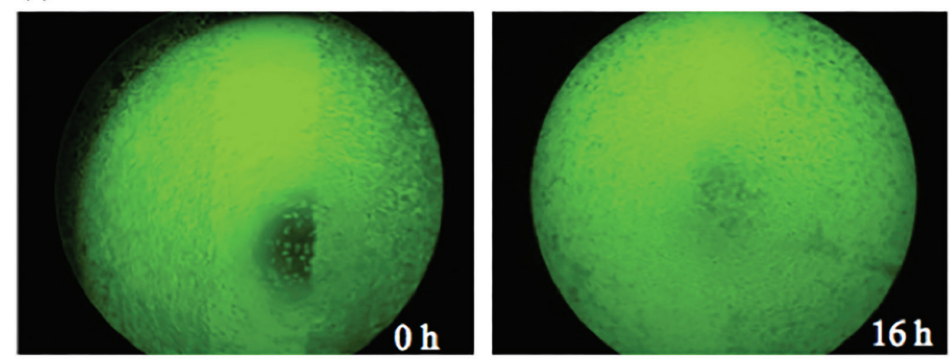

(b)

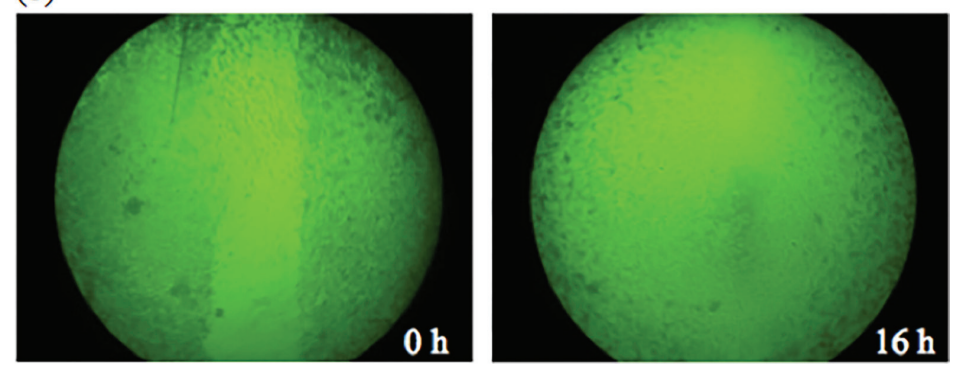

Figure 4. Wound closure effect of linear pohlianin B (2a) and linear ribifolin (4a) on neonatal human foreskin fibroblasts (HFF-1): (a) photographs of the wound healing assay at 0 and $16 \mathrm{~h}$ for $\mathbf{2 a}$, and (b) photographs of the wound healing assay at 0 and $16 \mathrm{~h}$ for $\mathbf{4 a}$.

After the evaluation of the capillary tubule formation, quantification of the collagen was assessed through a colorimetric enzymatic method known as the hydroxyproline assay (Table 3). Like the migration of fibroblasts, the deposition of collagen is a fundamental factor for the tissue repair process since fibroblasts are the primary collagen synthesizing cells. ${ }^{23}$ According to the literature and from a clinical point of view, this is one of the most important phases of healing because some features such as the rate, quality and amount of collagen deposition can determine the strength of the scar. ${ }^{23}$ Hydroxyproline is an important component of collagen due to its high content, and it acts by stabilizing helical structures. It is described as a non-proteinogenic amino acid and is widely restricted to collagen. In this way, evaluations of hydroxyproline levels are commonly used as an indicator of collagen content.

As expected, the results from the hydroxyproline assay demonstrated that both linear peptides (2a and $\mathbf{4 a}$ ) 

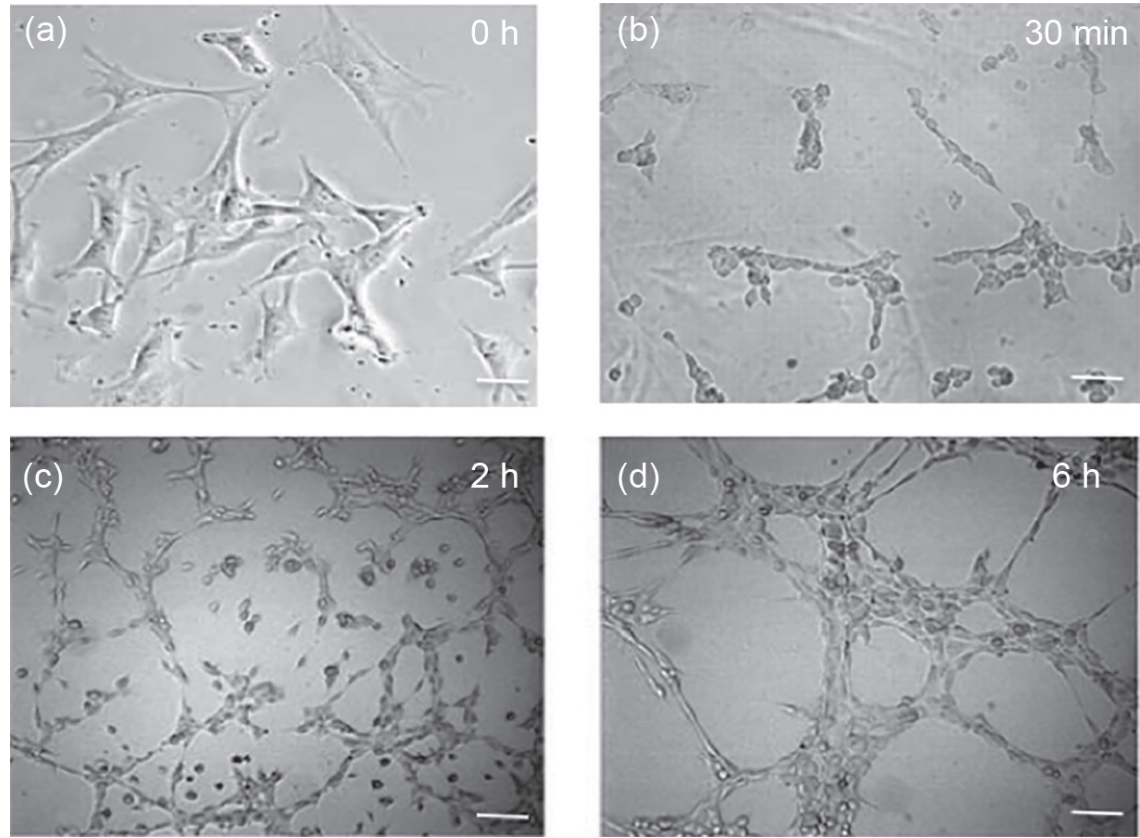

Figure 5. Representative images of the capillary tubule formation in the presence of linear pohlianin B (2a) at the concentration of $20 \mu \mathrm{M}$ : (a) cells at time $0 \mathrm{~h}$, (b) $30 \mathrm{~min}$ after addition of the peptide, (c) and (d) 2 and $6 \mathrm{~h}$ after addition of the peptide, respectively, bar $=200 \mu \mathrm{m}$.
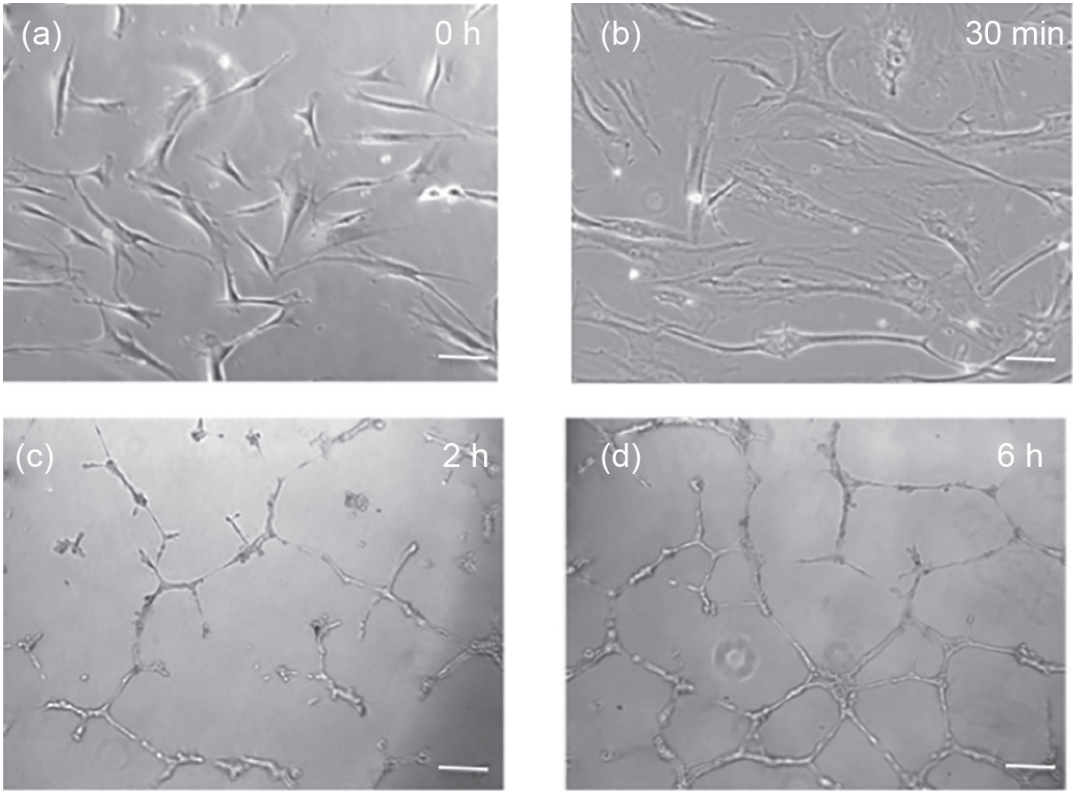

Figure 6. Representative images of the capillary tubule formation in the presence of linear ribifolin (4a) at the concentration of $20 \mu \mathrm{M}$ : (a) cells at time $0 \mathrm{~h}$, (b) $30 \mathrm{~min}$ after addition of the peptide, (c) and (d) 2 and $6 \mathrm{~h}$ after addition of the peptide, respectively, bar $=200 \mu \mathrm{m}$.

were able to increase the amount of hydroxyproline over time $(0-24 \mathrm{~h})$; both peptides are thus strongly related to the collagen deposition (Table 3). After $24 \mathrm{~h}$, the amount of hydroxyproline was nearly 2 times higher than the blank for both evaluated peptides. As observed, the linear peptide ribifolin (4a) exhibited the highest potency $\left(0.7210 \mu \mathrm{g} \mu \mathrm{L}^{-1}\right)$, which was in agreement with the results of the migration assay (Figures 2 and 3).

In fact, the physicochemical properties that affect fibroblast migration processes and collagen deposition are not fully understood, and further investigations involving in vivo assays still must be continued. However, one of the main advantages is the fact that the relevant peptides are small sized (up to eight amino acids) and easy to obtain by synthetic methods since they present simple structural frameworks. Our lead discovery strategy, inspired by the structure of natural orbitides, led to the identification of peptides (2a and $\mathbf{4 a}$ ) that exhibited high potential to promote HFF-1 migration and collagen deposition with no toxicity. These data also provide evidence that the obtained 
Table 3. Results of the hydroxyproline assay performed over time (0 to $24 \mathrm{~h}$ ) for linear pohlianin B (2a) and linear ribifolin (4a)

\begin{tabular}{lcccc}
\hline \multirow{2}{*}{ Sample } & \multicolumn{4}{c}{ Hydroxyproline content $/\left(\mu \mathrm{g} \mu \mathrm{L}^{-1}\right)$} \\
\cline { 2 - 5 } & $0 \mathrm{~h}$ & $6 \mathrm{~h}$ & $12 \mathrm{~h}$ & $24 \mathrm{~h}$ \\
\hline Linear pohlianin B (2a) & 0.1102 & 0.3072 & 0.5484 & 0.6632 \\
Linear ribifolin (4a) & 0.1098 & 0.3136 & 0.6532 & 0.7210 \\
Blank & 0.1173 & 0.2231 & 0.2825 & 0.3144 \\
\hline
\end{tabular}

peptides might contribute to acceleration of the processes of wound healing and tissue repair.

Overall, these studies highlight the importance of designing and synthesizing peptides to explore the structure-property and structure-activity relationships, which will be valuable in the development of new peptide-based drug leads. The studies also demonstrate the significance of using natural products as starting points for the generation of simple and novel drug scaffolds.

\section{Conclusions}

These data report for the first time the involvement of synthetic linear peptides in the processes of cell migration in human neonatal foreskin fibroblasts. Analysis of fibroblast in vitro assays of eight distinct peptides (cyclic and linear) provided insight into fibroblast migration and collagen deposition, which are important processes involved in tissue repair. The promising results demonstrated that linear peptide analogues, originally designed from Jatropha's orbitides, can potentiate fibroblast migration and collagen deposition. These studies provide valuable information, and the obtained results highlight the significance of using natural products as starting points for the generation of novel drug scaffolds, as well as their further development as potential lead compounds. Orbitides present a great potential for bioprospection and peptidomimetic approaches, although it has become clear that orbitides are still underexplored despite the increasing number of compounds studied over the years. Thus, future research on the molecular mechanisms will contribute to and facilitate further investigations related to the potential use of peptides in wound therapy and other related diseases.

\section{Experimental}

\section{General information}

ESI-MS (electrospray ionization mass spectrometry) spectra were obtained with an UltrOTOF-Q (Bruker Daltonics MA, USA) spectrometer using $\left(\mathrm{N}_{2}\right)$ and $10 \mathrm{eV}$ for $\mathrm{MS}$ and $45 \mathrm{eV}$ for MS/MS in positive ionization mode. HPLC (high performance liquid chromatography) analytical analyses were carried out on a Shimadzu LC-6AD instrument with a Phenomenex C18 column $(4.6 \times 250 \mathrm{~mm}, 100 \AA$ pore size, $5 \mu \mathrm{m}$ particle size,

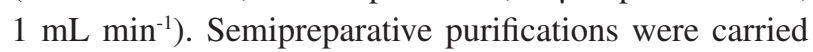
out with a Phenomenex C18 column $(21.20 \times 250 \mathrm{~mm}$,

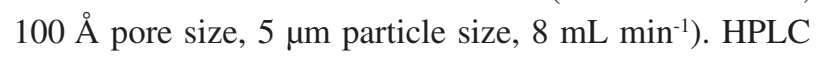
experiments were monitored using UV detection at wavelengths of 220 and $280 \mathrm{~nm}$.

Plant material

The latex of Jatropha mollissima (Pohl) Baill. was collected in September 2015 in the city of Araruna-PB, Brazil. A voucher specimen of Jatropha mollissima (Pohl) Baill. (No. 58187) was deposited at the Herbarium Prisco Bezerra, Federal University of Ceará, Brazil. The crude latex was obtained by cutting the stems, followed by dropwise collection, and the material was stored at $-20^{\circ} \mathrm{C}$. Aerial parts of Jatropha ribifolia (Pohl) Baill. were collected in September 2009 in the city of Maturéia-PB, Brazil. A voucher specimen of Jatropha ribifolia (Pohl) Baill. (No. 7243) was deposited at the Herbarium of Prof. Lauro Pires Xavier, Federal University of Paraíba, Brazil. The extractions of the plant material and isolation of the orbitides were accomplished according to the methods previously described in the literature. ${ }^{8,19}$

\section{Solid phase peptide synthesis}

Following a standard procedure, linear peptide analogues were synthesized using an SSPS Fmoc protecting group strategy. The synthesis started with the Fmoc-L-Gly Wang resin (substitution value $0.55 \mathrm{mmol} \mathrm{g}^{-1}$ ) on the scale of $0.4 \mathrm{mmol}$. The amino groups were deprotected with $20 \%$ piperidine in dimethylformamide (DMF) for $20 \mathrm{~min}$. The L-amino acids were coupled in excess $(0.8 \mathrm{mmol})$ using diisopropylcarbodiimide- $N$-hydroxybenzotriazole in $50 \%$ dichloromethane-dimethylformamide (DCM-DMF v/v). After $2 \mathrm{~h}$, couplings were monitored by the Kaiser ninhydrin test. After the amino acid sequences were complete, the cleavage from the resin and removal of side-chain 
protecting groups were simultaneously performed with a solution of TFA- $p$-cresol- $\mathrm{H}_{2} \mathrm{O}$ (90:5:5) for $2 \mathrm{~h}$. Then, the crude peptides were precipitated with anhydrous diethyl ether, separated from the soluble nonpeptide material by centrifugation, extracted into $0.045 \%$ TFA in water and lyophilized (equipment from Trade). Purification was accomplished by a semipreparative reversed phase HPLC C18 column and identified by ESI-MS. The fractions containing the desired compounds were collected, grouped and lyophilized.

\section{Cell culture}

The human cell lines were obtained from the Rio de Janeiro Cell Bank-BCRJ 0275 (BCRJ, Rio de Janeiro, Brazil). The HFF-1 fibroblasts were maintained in Dulbecco's modified Eagle's medium (DMEM) supplemented with $10 \%$ FBS. The cultures were maintained at $37^{\circ} \mathrm{C}$ in a $5 \% \mathrm{CO}_{2}$ humidified atmosphere. Cell viability was assessed using the trypan blue exclusion test before the experiments.

\section{Cytotoxicity assay}

The cytotoxicity to HFF-1 cells was measured using the MTS assay. Throughout the experiments, cells were plated in 96-well culture plates (100 $\mu \mathrm{L}$ of DMEM per well) at a density of $2 \times 10^{3}$ cells per well for HFF-1. After 24 and $72 \mathrm{~h}$, two concentrations ( 1 and $20 \mu \mathrm{M}$ ) of the test substances and doxorubicin (as a control) were added in triplicate to the wells. After 24 and $72 \mathrm{~h}$ of incubation at $37^{\circ} \mathrm{C}$ in a $5 \% \mathrm{CO}_{2}$ humidified atmosphere, $20 \mu \mathrm{L}$ of the MTS reagent (CellTiter $96^{\circledR}$ AQueous One Solution Cell Proliferation assay, Promega) were added to the wells, and the cells were incubated for $4 \mathrm{~h}$ at $37^{\circ} \mathrm{C}$. Absorbance was measured at $490 \mathrm{~nm}$ using a spectrophotometer (SpectraMax Plus384, Molecular Devices), and the percentage of viable cells was determined in relation to the control wells. At least two independent experiments in triplicate were carried out for each test compound.

\section{Wound healing assay}

The HFF-1 cells were seeded into 24-well culture plates (Becton-Dickinson) and cultivated until the cells formed a confluent monolayer. Wounds were created by horizontally scratching the monolayer with a sterile $100 \mu \mathrm{L}$ pipette tip. The cells were thereafter washed twice with phosphate buffered saline (PBS) to remove the detached cells. Then, growth medium was added containing different concentrations of the chemical compounds (10,
5, 2 and $1 \mu \mathrm{M})$ and incubated at $37^{\circ} \mathrm{C}$ with fetal bovine serum medium (10\% FBS). The cells were photographed under a $4 \times$ objective (Optiphase) at the beginning of the experiment $(0 \mathrm{~h})$ and after $16 \mathrm{~h}$ to assess the progression of cell migration into the wound. The images were analyzed using ImageJ software, ${ }^{24}$ and experiments were conducted in triplicate.

\section{Chamber cell migration assay}

Cell migrations were assayed with Boyden chambers (8.0- $\mu \mathrm{m}$ pore size, polyethylene terephthalate (PET) membrane, Falcon cell culture insert (Becton-Dickinson)). HFF-1 cells were trypsinized and counted. A total of $200 \mu \mathrm{L}$ containing 5-10 $\times 10^{4}$ cells in serum-free medium was added to the upper chamber, and $500 \mu \mathrm{L}$ of medium with $10 \%$ FBS were added to the lower chamber. The transwells were incubated for $16 \mathrm{~h}$ at $37^{\circ} \mathrm{C}$ with $5 \mu \mathrm{M}$ of the chemical compound in both the upper and lower chambers. Cells on the inside of the transwell inserts were removed with a cotton swab, and cells on the underside of the insert were fixed (methanol) and stained (toluidine blue). Photographs were taken, and the number of cells was counted to calculate the average number of cells that transmigrated. We used medium supplemented with $10 \%$ FBS as a positive control and serum-free medium as a true negative control. Data shown are representative of at least three experiments.

\section{Tubule formation assay}

Liquefied Matrigel Matrix (BD Biosciences) was used to coat the wells of a 24 -well plate ( $35 \mu \mathrm{L}$ per well), and then allowed to polymerize at $37^{\circ} \mathrm{C}$ for $30 \mathrm{~min}$. Trypsinharvested cells $\left(3 \times 10^{4}\right)$ suspended in $300 \mu \mathrm{L}$ of the fresh assay medium containing peptides were seeded onto Matrigel and incubated for $6 \mathrm{~h}$. Capillary-like structures within the Matrigel layer were then analyzed using a light microscope at $100 \times$ magnification. Each experiment was repeated three times.

\section{Hydroxyproline assay}

The hydroxyproline concentration was determined by the reaction of oxidized hydroxyproline with 4-(dimethylamino) benzaldehyde (DMAB), which resulted in a colorimetric $(560 \mathrm{~nm})$ product that was proportional to the hydroxyproline present. Initially, $10 \mu \mathrm{L}$ of the $1 \mathrm{mg} \mathrm{mL}^{-1}$ hydroxyproline standard solution were diluted with $90 \mu \mathrm{L}$ of water to prepare $0.1 \mathrm{mg} \mathrm{mL}^{-1}$ standard solutions. Then, $0,2,4,6,8$ and $10 \mu \mathrm{L}$ of the $0.1 \mathrm{mg} \mathrm{mL}^{-1}$ hydroxyproline standard solution were added to a 96 -well plate, generating 
0.0 (blank), 0.2, 0.4, 0.6, 0.8, and $1.0 \mu \mathrm{g}$ per well standards. Ten milligrams of cells were homogenized in $100 \mu \mathrm{L}$ of water and transferred to a pressure-tight vial. In a sequence, $100 \mu \mathrm{L}$ of a concentrated hydrochloric acid $(12 \mathrm{M} \mathrm{HCl})$ were added, capped tightly, and samples were hydrolyzed at $120^{\circ} \mathrm{C}$ for $3 \mathrm{~h}$. Then, $50 \mu \mathrm{L}$ of supernatant were transferred to a 96-well plate. All wells were evaporated (samples and standards) to dryness under vacuum. For the assay reaction, $100 \mu \mathrm{L}$ of the chloramine-T/oxidation buffer mixture were added to each well and incubated at room temperature for $5 \mathrm{~min}$. Then, $100 \mu \mathrm{L}$ of the diluted DMAB reagent were added to each well and incubated for $90 \mathrm{~min}$ at $60{ }^{\circ} \mathrm{C}$. The absorbance was measured at $560 \mathrm{~nm}$.

\section{Supplementary Information}

Supplementary information is available free of charge at http://jbcs.sbq.org.br as a PDF file.

\section{Acknowledgments}

The authors are thankful to the São Paulo Research Foundation (FAPESP), grant No. 2015/09533-7, for the scholarship awarded to S. D. R. and for the MEFP FAPESP grant No. 2017/17098-4. The authors appreciate the National Council of Technological and Scientific Development (CNPq) grant No. 162855/2015-0 of MEFP. The SISBIOTA-CNPq-FAPESP grant No. 2010/52327-5, CEPID-FAPESP grant No. 2013/07600-3, and INCT-CNPq grant No. 465637/2014-0 are appreciated as financial support.

\section{References}

1. Craik, D. J.; Lee, M. H.; Rehm, F. B. H.; Tombling, B.; Doffek, B.; Peacock, H.; Bioorg. Med. Chem. 2017, 26, 2737.

2. Arnison, P. G.; Bibb, M. J.; Bierbaum, G.; Bowers, A. A.; Bugni, T. S.; Bulaj, G.; Camarero, J. A.; Campopiano, D. J.; Challis, G. L.; Clardy, J.; Cotter, P. D.; Craik, D. J.; Dawson, M.; Dittmann, E.; Donadio, S.; Dorrestein, P. C.; Entian, K. D.; Fischbach, M. A.; Garavelli, J. S.; Goransson, U.; Gruber, C. W.; Haft, D. H.; Hemscheidt, T. K.; Hertweck, C.; Hill, C.; Horswill, A. R.; Jaspars, M.; Kelly, W. L.; Klinman, J. P.; Kuipers, O. P.; Link, A. J.; Liu, W.; Marahiel, M. A.; Mitchell, D. A.; Moll, G. N.; Moore, B. S.; Muller, R.; Nair, S. K.; Nes, I. F.; Norris, G. E.; Olivera, B. M.; Onaka, H.; Patchett, M. L.; Piel, J.; Reaney, M. J.; Rebuffat, S.; Ross, R. P.; Sahl, H. G.; Schmidt, E. W.; Selsted, M. E.; Severinov, K.; Shen, B.; Sivonen, K.; Smith, L.; Stein, T.; Sussmuth, R. D.; Tagg, J. R.; Tang, G. L.; Truman, A. W.; Vederas, J. C.; Walsh, C. T.; Walton, J. D.;
Wenzel, S. C.; Willey, J. M.; van der Donk, W. A.; Nat. Prod. Rep. 2013, 30, 160.

3. Shim, Y. Y.; Young, L. W.; Arnison, P. G.; Gilding, E.; Reaney, M. J.; J. Nat. Prod. 2015, 78, 652.

4. Picchi, D. G.; Altei, W. F.; Saito, M. S.; Bolzani, V. S.; Cilli, E. M.; Quim. Nova 2009, 32, 1277.

5. Ramalho, S. D.; Pinto, M. E. F.; Ferreira, D.; Bolzani, V. S.; Planta Med. 2018, 84, 567.

6. Sabandar, C. W.; Ahmat, N.; Jaafar, F. M.; Sahidin, I.; Phytochemistry 2013, 85, 29.

7. Queiroz, M. F.; Fernandez, P. D.; Neto, J. D.; Arriel, N. H. C.; Marinho, F. J. L.; Leite, S. F.; Rev. Bras. Eng. Agr. Amb. 2013, 17, 413.

8. Pinto, M. E.; Batista Jr., J. M.; Koehbach, J.; Gaur, P.; Sharma, A.; Nakabashi, M.; Cilli, E. M.; Giesel, G. M.; Verli, H.; Gruber, C. W.; Blanch, E. W.; Tavares, J. F.; da Silva, M. S.; Garcia, C. R.; Bolzani, V. S.; J. Nat. Prod. 2015, 78, 380.

9. Altei, W. F.; Picchi, D. G.; Abissi, B. M.; Giesel, G. M.; Flausino Jr., O.; Reboud-Ravaux, M.; Verli, H.; Crusca Jr., E.; Silveira, E. R.; Cilli, E. M.; Bolzani, V. S.; Phytochemistry 2014, 107, 96.

10. Craik, D. J.; Allewell, N. M.; J. Biol. Chem. 2012, 287, 27000.

11. Machado, A.; Liria, C. W.; Proti, P. B.; Remuzgo, C.; Miranda, T. M.; Quim. Nova 2004, 27, 789.

12. Lau, J. L.; Dunn, M. K.; Bioorg. Med. Chem. 2018, 26, 2707.

13. Craik, D. J.; Fairlie, D. P.; Liras, S.; Price, D.; Chem. Biol. Drug Des. 2013, 81, 147.

14. Yamada, K. M.; J. Clin. Invest. 2000, 105, 1509.

15. Kohyama, T.; Yamauchi, Y.; Takizawa, H.; Kamitani, S.; Kawasaki, S.; Nagase, T.; Mol. Cell. Biochem. 2010, 337, 81.

16. Bizzarro, V.; Fontanella, B.; Carratu, A.; Belvedere, R.; Marfella, R.; Parente, L.; Petrella, A.; PLoS One 2012, 7, 9.

17. Guo, A.; Song, B.; Reid, B.; Gu, Y.; Forrester, J. V.; Jahoda, C. A.; Zhao, M.; J. Invest. Dermatol. 2010, 130, 2327.

18. Li, W.; Fan, J.; Chen, M.; Guan, S.; Sawcer, D.; Bokoch, G. M.; Woodley, D. T.; Mol. Biol. Cell 2004, 15, 309.

19. Auvin-Guette, C.; Baraguey, C.; Blond, A.; Xavier, H. S.; Pousset, J.-L.; Bodo, B.; Tetrahedron 1999, 55, 11510.

20. Craik, D. J.; Shim, Y. Y.; Goransson, U.; Moss, G. P.; Tan, N.; Jadhav, P. D.; Shen, J.; Reaney, M. J.; Biopolymers 2016, 106, 924.

21. Li, J.; Zhang, Y. P.; Kirsner, R. S.; Microsc. Res. Tech. 2003, 60, 114.

22. Berthod, F.; Germain, L.; Tremblay, N.; Auger, F. A.; J. Cell. Physiol. 2006, 207, 498.

23. Witte, M. B.; Barbul, A.; Surg. Clin. North Am. 1997, 77, 528. 24. http://imagej.net, accessed in May 2019.

Submitted: February 7, 2019

Published online: May 21, 2019 